\title{
Erratum to: Decitabine-induced apoptosis is derived by Puma and Noxa induction in chronic myeloid leukemia cell line as well as in PBL and is potentiated by SAHA
}

Barbora Brodská · Petra Otevřelová • Aleš Holoubek

Published online: 23 February 2012

(C) Springer Science+Business Media, LLC. 2012

Erratum to: Mol Cell Biochem (2011) 350:71-80

DOI 10.1007/s11010-010-0683-3

The acknowledgment of grants, now printed below, was erroneously specified in the original publication of this article.
This work was supported by the Grant NS 9637-4 from the Ministry of Health of the Czech Republic and the Grant No 301/09/1026 from the Grant Agency of the Czech Republic.

Everything else in the article remains correct.

The online version of the original article can be found under doi:10.1007/s11010-010-0683-3.

B. Brodská $(\bowtie) \cdot$ P. Otevřelová · A. Holoubek

Institute of Hematology and Blood Transfusion, U Nemocnice 1,

12820 Prague 2, Czech Republic

e-mail: brodska@uhkt.cz 